\author{
Military Technical College \\ Kobry El-Kobbah, \\ Cairo, Egypt
}

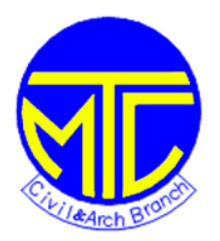

\title{
EXPERIMENTAL AND NUMERICAL SIMULATION OF PROJECTILE PENETRATION IN CONCRETE
}

$8^{\text {th }}$ International Conference on Civil and Architecture

Engineering

ICCAE-8-2010

\section{By}

Laissy * M.Y Abdel-Latif ** W.M Abdel-Wahab *** M.M

\section{Abstract}

For protective structures, concrete is the commonly used material. These protective structures are usually exposed to a dynamic loading rather than static loading which arises from either explosions or penetration of projectiles. Military protective structures can also be exposed to both cases which can caused by military weapons. Traditionally, for prediction of the depth of penetration and crater size from projectiles, empirical relationships are used as discussed in TM5-1300 [6]. This paper presents numerical and experimental simulations of concrete penetration by $23 \mathrm{~mm}$ steel projectiles with a velocity of $969 \mathrm{~m} / \mathrm{s}$ and a comparison between the results and existing experimental investigations. The analysis is executed with AUTODYN [8]. To learn more about the structural behavior of concrete subjected to severe loading and to gain confidence in AUTODYN which is a powerful tool utilizing advanced non-linear FE analysis; this paper describes the methods used to validate ANSYS-AUTODYN capabilities and presents the results of the validation for a concrete model. The calculation is achieved using the empirical relationship from TM5-1300 and these data are compared to the obtained data from AUTODYN and the physical experiment.

Keywords: Sandwich Panels, Suppressive Core, Penetration, Projectiles.

* Ph. D. Applicant, Cairo University, Egypt.

** Associate Professor of Construction Engineering, Department of Civil

Engineering, Faculty of Engineering, Cairo University, Egypt.

*** Brig. D, Military Technical College, Egyptian Armed Forces, Egypt. 


\section{Objective}

The objective of this paper is to validate and gain confidence in ANSYS-AUTODYN to describe the use the non-linear finite element (FE) method for concrete penetration analysis and to show examples where 3-dimensional (3D) numerical analysis software tools have been used in both the design process as well as in safety assessment studies. Comparison of empirical, numerical and experimental data of penetration problems on concrete as well as the performance of the simulation for the penetration depth will be illustrated.

\section{Introduction}

A great range of penetration physical processes must be taken into account in order to be accurately characterized. It is the responsibility of the engineer/scientist/designer to consider these complexes and to interact with it using the appropriate techniques. This paper will represent three techniques that can be applied. First, hand calculation which can be applied only to the simplest, highly idealized problems that are practically solvable. Then, physical experiments, that is being used and developed for study due to the difficulties in modeling the highly nonlinear problems, will be applied for the same problem. Finally, a numerical software tool that offers another approach to impact studies will be applied. Where numerical techniques are suitable for solving a wider range of problems [1], they enable great savings in the cost of investigative physical experiments and allow the analyst to look at a "perfectly instrumented numerical experiment". Thus, he can examine the parameters that are virtually impossible to be measured in physical experiments in whatever detail he can see appropriate.

\section{Penetration and Perforation of projectiles:}

The penetration of projectiles into targets involves complex mechanical interactions [2]. By convention [1] the following simplifying definition are adopted. When a projectile enters a target did not passes through it so this projectile it is said 'penetrated' [4]. On the other hand, when a projectile passes completely through a target, it is said 'perforated' [5]. The depth of penetration is given by the distance as show in Figure 2a and Figure 2b.

\section{Analysis and Modeling of Concrete Penetration:}

\subsection{Hand calculation analysis:}

From the technical manual TM5-1300 [6], a certain amount of experimental data, which is analogous to primary fragment penetration, has been accumulated in connection with projects to determine the effects of bombs and projectile impact on concrete structures [7]. This data has been analyzed in order to develop relationships for the amount of fragment penetration into concrete elements in terms of the physical properties of both the metal fragment and the concrete. A general expression 
for the maximum penetration into a massive concrete slab by an armor-piercing fragment has been obtained as follows:

$$
\mathrm{X}_{\mathrm{f}}=4.0 \times 10^{-6} \mathrm{KND} \mathrm{d}^{1.2} \mathrm{vs}^{1.8}+\mathrm{d} \quad \text { for } \mathrm{X}_{\mathrm{f}}>2 \mathrm{~d}
$$

and

$$
\mathrm{K}=12.91 /\left(\mathrm{f}^{\prime} \mathrm{c}\right)^{1 / 2}
$$

Where:

$\mathrm{X}_{\mathrm{f}}=$ penetration distance by armor-piercing steel fragments "inch"

$\mathrm{K}=$ penetrability constant

$\mathrm{N}=$ nose shape factor as defined in Figure 1

$\mathrm{D}=$ caliber density as defined in Figure $1 " \mathrm{oz} . / \mathrm{in}^{3 "}$

$\mathrm{d}=$ fragment diameter "inch"

$\mathrm{v}_{\mathrm{s}}=$ striking velocity " fps"

$\mathrm{f}^{\prime} \mathrm{c}=$ concrete strength " psi"

Projectile weight $=6.7$ onuses .

Projectile diameter $=23 \mathrm{~mm}=0.91$ inch .

Striking Velocity $=969 \mathrm{~m} / \mathrm{s}=3182.415 \mathrm{fps}$

Concrete strengths other than 4.000 psi is " $\mathrm{f}^{\prime} \mathrm{c} "$

Penetrability constant "K" $=12.91 /\left(\mathrm{f}^{\prime} \mathrm{c}\right)^{1 / 2}$

$$
\begin{aligned}
& \mathrm{K}=12.91 /(2500)^{1 / 2} \\
& \mathrm{~K}=.258
\end{aligned}
$$

Nose Shape factor "N" $N=0.72+0.25 \sqrt{\frac{r}{d}-0.25}$

$$
\begin{gathered}
N=0.72+0.25 \sqrt{\frac{11.5}{23}-0.25} \\
N=0.845
\end{gathered}
$$

Caliber Density "D" $=\mathrm{W}_{\mathrm{f}} / \mathrm{d}^{3}$

$$
\mathrm{D}=\mathrm{W}_{\mathrm{f}} / \mathrm{d}^{3}=6.7 /(0.91)^{1 / 3}=8.89 \mathrm{oz} . / \mathrm{in}^{3}
$$

$\mathrm{X}_{\mathrm{f}}=4.0 \times 10^{-6} \mathrm{KND} \mathrm{d}^{1.2} \mathrm{vs}^{1.8}+\mathrm{d}$

$$
\begin{aligned}
\mathrm{X}_{\mathrm{f}} & =4.0 \times 10^{-6}(0.258 * 0.845 * 8.89) *(0.91)^{1.2} *(3182.415)^{1.8}+0.91 \\
& =14.88 \mathrm{inch} \\
& =37.799 \mathrm{~cm} \approx 38 \mathrm{~cm}
\end{aligned}
$$

\subsection{Experimental Analysis:}

\subsubsection{Test set up}

The gas gun test were carried out to investigate the penetration depth of the concrete model exposed to ballistic impact (very high velocity of projectile) as shown in Figure 3. This test was carried out according to laboratories of USA army corps of engineering (ACE) in laboratories of military factory no.45 using an Aircraft $23 \mathrm{~mm}$ cannon as shown in Figures 3 and 4. The used projectile was 
blunt-nose steel penetrator $23 \mathrm{~mm}$ diameters and $64 \mathrm{~mm}$ length as shown in Figure 5 and 6 which illustrate the dimension and details of the penetrator, the material prosperities of the penetrator are listed in Table (1). The impact velocity was measured and reported for every shot with electro-optical velocity measurement device which is connected with computer as shown in Figures 8 and 9 (it was $969 \mathrm{~m} / \mathrm{sec}$ ).

The illustrated test model in Figure 10 is formed of four concrete blocks with the dimension of $(0.6 \mathrm{~m} \times 0.6 \mathrm{~m} \times 1.0 \mathrm{~m})$. The model boundary condition was simply supported on the ground and the models back side is fixed. The target model is formed of plain concrete.

\subsubsection{Experimental Test Result}

The $23 \mathrm{~mm}$ projectile impacted the concrete model which consists of two concrete blocks and has perforated from the first block then, it penetrated into the second block for a distance of $0.072 \mathrm{~m}$. The total penetration depth of the projectile into the model is $0.372 \mathrm{~m}$.

\subsection{Numerical analysis:}

\subsubsection{Description of finite element model}

The finite element program AUTODYN was used to create finite element model for the previous experimental model. This was to simulate the penetration process of projectiles into the concrete model. The material or component is discredited into forming cells or meshes. Each mesh interacts with another one by defined strength model for each material that has an equation of state. The line of interaction between materials is defined; time step is determined in order to satisfy the stability condition for the problem. Finally, a matrix of unknowns is solved for non-linear system indicating each effect of stresses on the whole materials.

\subsubsection{Material Description}

\subsubsection{Projectile Material}

The material model used to simulate the projectile in the model is (STEEL 4340) which was chosen from the AUTODYN library. The equation of state is linear equation of state, and the strength model is Johnson Cook strength model, whereas the failure model was (None) and the erosion model was selected to be Instantaneous geometrical strain. The data defines of the penetrator material in the hydrocode were chosen from the library and modified, according to used material listed in Table (2). 


\subsubsection{Concrete Material}

The material model used to simulate the plain concrete in the used model is (CONCRETE $35 \mathrm{MPa}$ ). This material model was chosen from the AUTODYN library. The equation of state was P-Alpha equation of state, and the strength model was RHT CONCRETE strength model. The failure model was RHT CONCRETE and the erosion model was selected to be instantaneous geometrical strain. The data defines of the concrete material in the hydrocode were chosen from the library and modified, according used material listed in Table (3).

\subsubsection{Geometry and Mesh Description}

Lagrange processor has been used in AUTODYN for the analyses. In this paper, the considered target panel was plain concrete. Projectile and the concrete target are modeled as Lagrangian meshes in the model. All parts were symmetric on $\mathrm{X}=0$ and $\mathrm{Y}=0$ planes to reduce the size of the computational domain. The geometry of the projectile part is defined in the model using a structural Lagrangian mesh. Due to the symmetric conditions, the projectile geometry, which is $23 \mathrm{~mm}$ diameter and $64 \mathrm{~mm}$ length is modeled as a 1/4 cylinder, it was divided to nodes in the I, $\mathrm{j}$, k-directions. This IJK-index is known as a Cartesian co-ordinate system. The projectile part filled material is (STEEL 4340) Figure 7, shows the geometry and mesh description for the projectile part.

For plain concrete model, concrete material (Conc.35MPa) is defined using a structural Lagrangian mesh. Due to the symmetric conditions, the geometry of the model is modeled as $1 / 4$ box and filled with it Figure 12 shows the geometry of model.

\subsubsection{Numerical Test Result}

From the result we found that the penetration of the projectile is almost $34.41 \mathrm{~cm}$ as the projectile velocity approaches to zero.

\section{Result Analysis:}

The penetration depth of the projectile into the model is shown in Figure 13 and 14 which present the projectile penetration depth time history for the model. Analysis with AUTODYNE for the concrete target was made by using the RHT model.

The $23 \mathrm{~mm}$ projectile stroking velocity with the concrete model is $969 \mathrm{~m} / \mathrm{s}$. For this experiment, the Lagrangian method was used for the numerical analyses. The model and the projectile were meshed into nodes and elements to produce accurate results.

The results gained from AUTODYNE program represented that the $23 \mathrm{~mm}$ projectile penetrated the concrete model for a distance of $0.38 \mathrm{~m}$ as illustrated in 
Figure 13 before the Z-velocity as well as the Z-force decline to reaches zero (Figure 14 and 15).

The maximum depth of penetration was $34.41 \mathrm{~cm}$, then the projectile stop and reflected with negative velocity as shown in Figure 13.

\section{Conclusion}

From the previous study, the following conclusions can be drawn out:

1. The AUTODYNE code satisfactory simulates the penetration experimental tests.

2. The response of concrete panel under the penetration load can be simulated using ANSYS software, it has the advantage, and thus it has higher analysis precision, compared to the common analysis.

3. The penetration distance of a projectile is being affected by many parameters such as nose shape factor because the penetration of projectile into targets involves complex mechanical interactions were AUTODYN has proven its efficiency in dealing with it.

4. Due to the time consuming and the expensive cost of experimental work, AUTODYN software can be used successfully as an alternative means to study different parameters that can affect the behavior of different sandwich panels with suppressive cores.

\section{References}

[1] "ANSYS Theory Reference", ANSYS, Inc., 1997.

[2] Joosef, L.: "Dynamic Behavior of Concrete Structures subjected to Blast and

Fragment Impacts", Chalmers University of Technology, Sweden, 2002.

[3] Hetherington, J.G.: "The Terminal Ballistic performance of Small to Medium Caliber Kinetic Energy Ammunition", School of Mechanical, Materials and Civil Engineering, Royal Military College of Science (Cranfield) Report No 0303-003, 1984.

[4] Johanson G. R.; Beissel S. R.; Homquist T. J. and Frew D. J.: "Computed radial stresses in a concrete target penetrated by a steel projectile" Fifth International Conference on Structure under Shock and Impact V, pp. 794-806,1998.

[5] Recht, R.F.: "Ballistic Perforation Dynamic of Armor-Piercing Projectiles", NWC TP4532, Naval Weapons Center, China Lake, California, 1967.

[6] TM5-1300: "Structures to Resist the Effects of Accidental Explosion", Department of Defense, USA, 2008.

[7] Li, Q.M.; Reid, S.R; Wen, H.M. and Telford, A.R.: "Local impact effects of hard missiles on concrete targets", International Journal of Impact Engineering, Vol. 32, pp. 224-284, 2005.

[8] "AUTODYN Interactive Non-Linear Dynamic Analysis software", Theory Manual, Century Dynamics Company, Inc., 2005. 
Table (1) Mechanical properties of the 23 AP projectile materials

\begin{tabular}{|c|c|c|c|}
\hline $\begin{array}{c}\text { Brinell hardness } \\
\text { Number }[\mathrm{HB}]\end{array}$ & $\begin{array}{c}\text { Yield } \\
\text { strength }\end{array}$ & $\begin{array}{c}\text { Ultimate } \\
\text { strength, }\end{array}$ & $\begin{array}{c}\text { Strain to fracture } \\
{[\%]}\end{array}$ \\
\hline 475 & 1726 & 1900 & 7 \\
\hline
\end{tabular}

Table (2) The data defines the projectile materials

\begin{tabular}{|l|c|l|c|}
\hline $\begin{array}{l}\text { Reference Density } \\
\left(\mathrm{gm} / \mathrm{cm}^{3}\right)\end{array}$ & 7.83 & $\begin{array}{l}\text { Hardening constant } \\
(\mathrm{Kpa})\end{array}$ & $\begin{array}{c}1.7851 \mathrm{E} \\
7\end{array}$ \\
\hline Bulk Modulus (Kpa) & $1.67 \mathrm{E} 8$ & Hardening exponent & 0.26 \\
\hline $\begin{array}{l}\text { Reference temperature } \\
(\mathrm{K})\end{array}$ & 300 & Strain rate constant & 0.014 \\
\hline $\begin{array}{l}\text { Specific heat (C.V.) } \\
(\mathrm{j} / \mathrm{kgK})\end{array}$ & 477 & $\begin{array}{l}\text { Thermal softening } \\
\text { exponent }\end{array}$ & 1.03 \\
\hline Shear modulus (Kpa) & $7.98 \mathrm{E} 7$ & Melting temperature (k) & 1793 \\
\hline Yield stress (Kpa) & $1.726 \mathrm{E}$ & Ref. Strain Rate (/s) & 1 \\
\hline
\end{tabular}


Proceedings of the $\boldsymbol{8}^{\text {th }}$ ICCAE-8 Conference, 25-27 May, 2010

\begin{tabular}{|l|l|}
\hline SA & 9 \\
\hline
\end{tabular}

Table (3) Data defines the concrete materials

\begin{tabular}{|c|c|c|c|}
\hline $\begin{array}{l}\text { Porous density } \\
\left(\mathrm{gm} / \mathrm{cm}^{3}\right)\end{array}$ & 2.75 & $\begin{array}{l}\text { Failure Surface parameter } \\
\text { A }\end{array}$ & 2 \\
\hline $\begin{array}{l}\text { Porous } \\
\text { density }\left(\mathrm{gm} / \mathrm{cm}^{3}\right)\end{array}$ & 2.314 & $\begin{array}{l}\text { Failure Surface exponent } \\
\mathrm{N}\end{array}$ & 0.7 \\
\hline $\begin{array}{l}\text { Porous sound speed } \\
(\mathrm{m} / \mathrm{s})\end{array}$ & 2.92E3 & $\begin{array}{l}\text { Tens./Comp. Meridian } \\
\text { Ration }\end{array}$ & 0.6805 \\
\hline $\begin{array}{l}\text { Initial compaction } \\
\text { pressure (Kpa) }\end{array}$ & $2.33 \mathrm{E} 4$ & Brittle to Ductile Transit & 0.0105 \\
\hline $\begin{array}{l}\text { Solid compaction } \\
\text { pressure (Kpa) }\end{array}$ & 6E6 & G (elas.)/G (elas.-plas.) & 2 \\
\hline $\begin{array}{l}\text { Compaction exponent } \\
\mathrm{n}\end{array}$ & 3 & Compaction curve & $\begin{array}{l}\text { Standar } \\
\quad \mathrm{d}\end{array}$ \\
\hline Solid EOS & $\begin{array}{l}\text { Polynomi } \\
\text { al }\end{array}$ & Elastic Strength /ft & 0.7 \\
\hline $\begin{array}{l}\text { Bulk Modulus A1 } \\
(\mathrm{kPa})\end{array}$ & $3.527 \mathrm{E} 7$ & Elastic Strength /fc & 0.53 \\
\hline Parameter A2 (kPa) & $3.958 \mathrm{E} 7$ & $\begin{array}{l}\text { Use cap on Elastic } \\
\text { Surface }\end{array}$ & 1 \\
\hline Parameter A3 (kPa) & 9.04E6 & $\begin{array}{l}\text { Residual Strength Const. } \\
\text { B }\end{array}$ & 1.5 \\
\hline Parameter B0 & 1.22 & $\begin{array}{l}\text { Residual Strength } \\
\text { exponent M }\end{array}$ & 0.61 \\
\hline Parameter B1 & 1.22 & $\begin{array}{l}\text { Comp. Strain Rate } \\
\text { Exponent a }\end{array}$ & 0.032 \\
\hline Parameter T1 (kPa) & $3.527 \mathrm{E} 7$ & $\begin{array}{l}\text { Tens. Strain Rate } \\
\text { Exponent D }\end{array}$ & 0.025 \\
\hline Parameter T2 (kPa) & 0 & $\begin{array}{l}\text { Max. Fracture strength } \\
\text { Ratio }\end{array}$ & $1 \mathrm{E} 20$ \\
\hline
\end{tabular}


Proceedings of the $\boldsymbol{8}^{\text {th }}$ ICCAE-8 Conference, 25-27 May, 2010

\begin{tabular}{|l|l|}
\hline SA & 9 \\
\hline
\end{tabular}

\begin{tabular}{|l|c|l|c|}
\hline $\begin{array}{l}\text { Reference temperature } \\
(\mathrm{K})\end{array}$ & $3 \mathrm{E} 2$ & Damage Constant D1 & 0.04 \\
\hline $\begin{array}{l}\text { Specific heat }(\mathrm{C} . \mathrm{V} .) \\
\text { (j/kgK) }\end{array}$ & $6.54 \mathrm{E} 2$ & Damage Exponent D2 & 1 \\
\hline Shear modulus $(\mathrm{kPa})$ & $1.67 \mathrm{E} 7$ & Min. strain to failure & 0.01 \\
\hline $\begin{array}{l}\text { Compressive strength } \\
\text { fc }(\mathrm{kPa})\end{array}$ & $3.50 \mathrm{E} 4$ & $\begin{array}{l}\text { Residual Shear Modulus } \\
\text { Frac. }\end{array}$ & 0.13 \\
\hline Tensile strength ft/fc & 0.088 & Tensile Failure Model & $\begin{array}{c}\text { Hydro } \\
\text { Tens. }\end{array}$ \\
\hline Shear strength fs/fc & 0.18 & Erosion strain & 0.7 \\
\hline
\end{tabular}

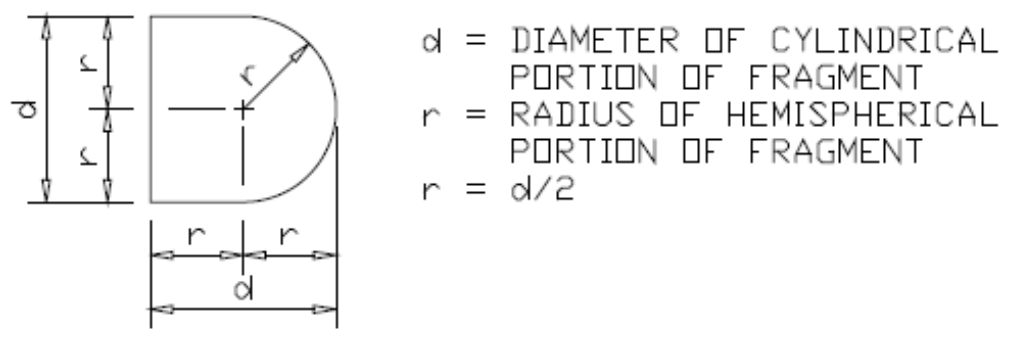

Figure 1: Shape of standard primary fragments

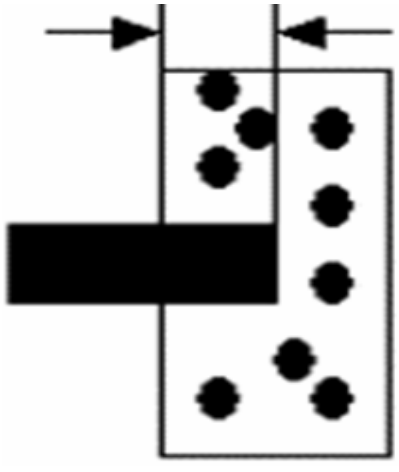

(a)

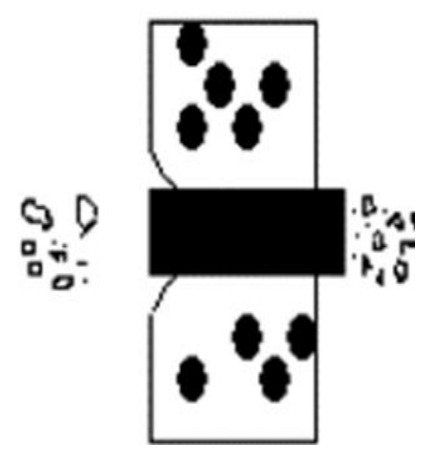

(b)

Figure 2: Penetration and perforation phenomena 


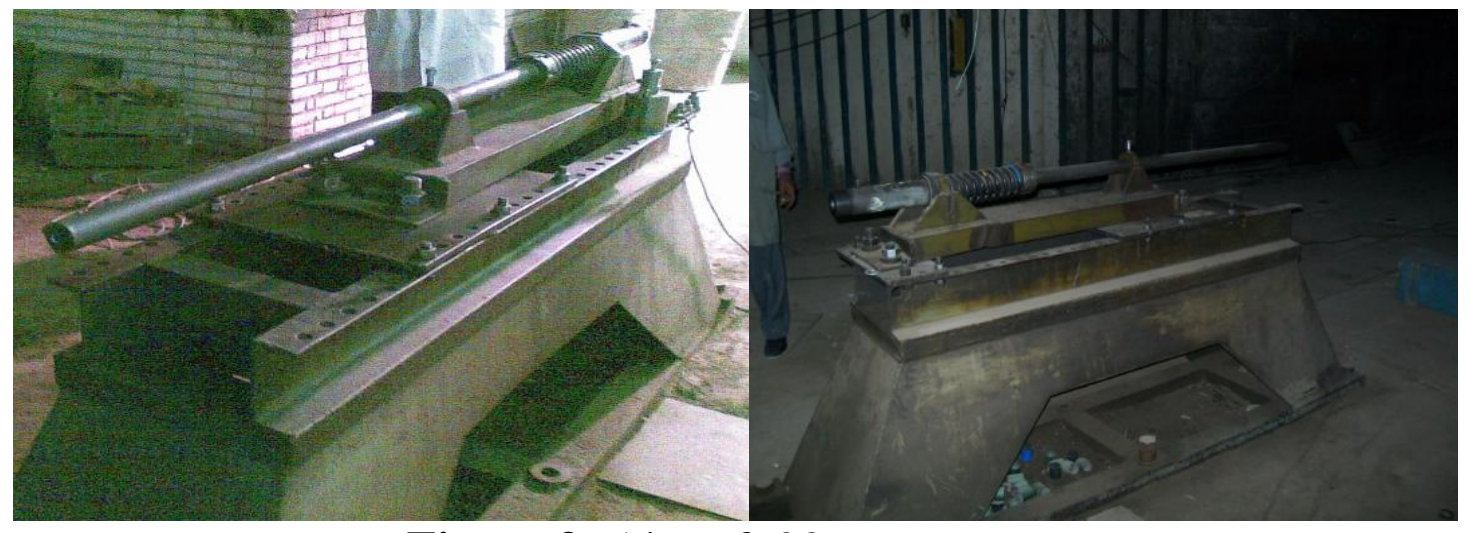

Figure 3: Aircraft $23 \mathrm{~mm}$ cannon

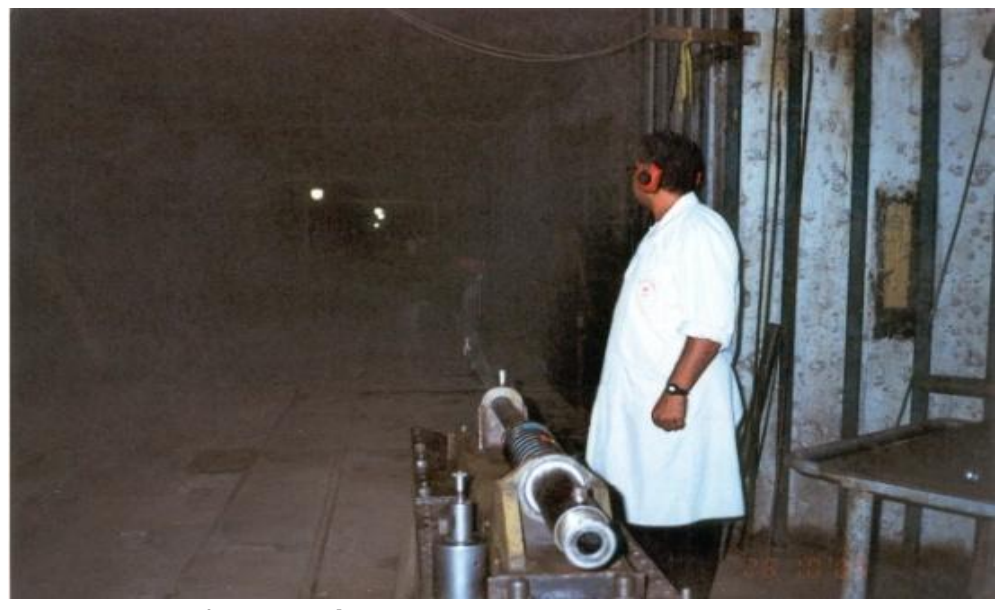

Figure 4: Aircraft $23 \mathrm{~mm}$ cannon

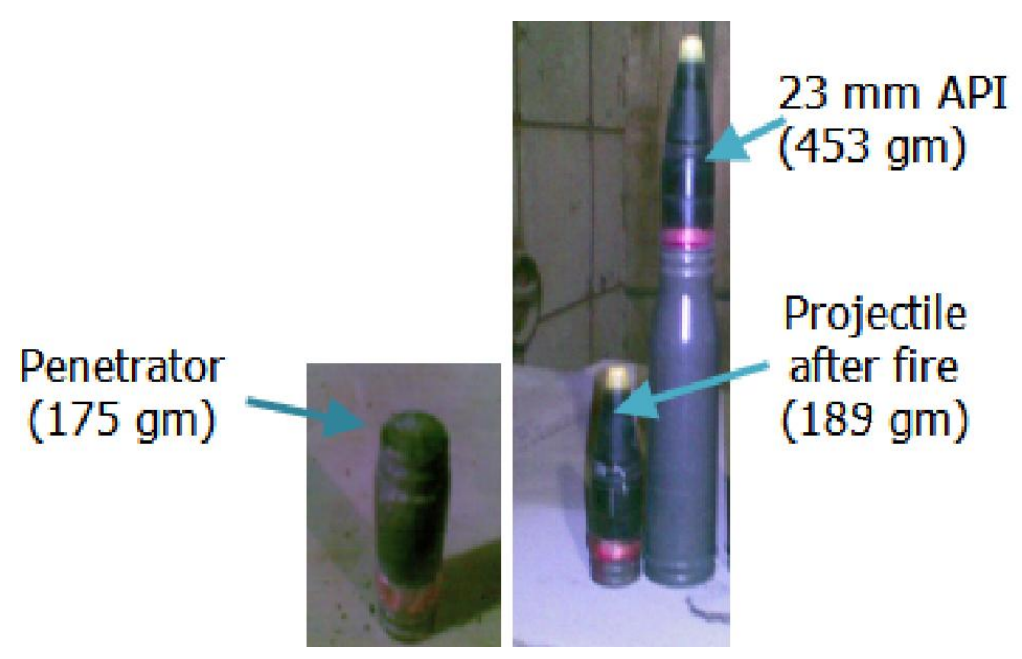

Figure 5: Different firing stages of $23 \mathrm{~mm}$ API projectile 


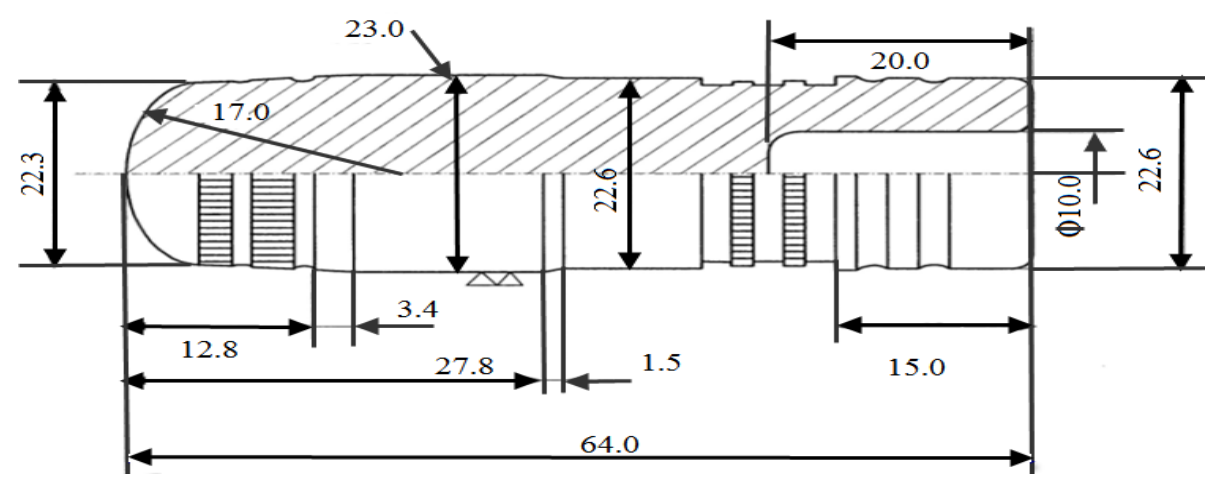

Figure 6: Dimension of $23 \mathrm{~mm}$ API projectile

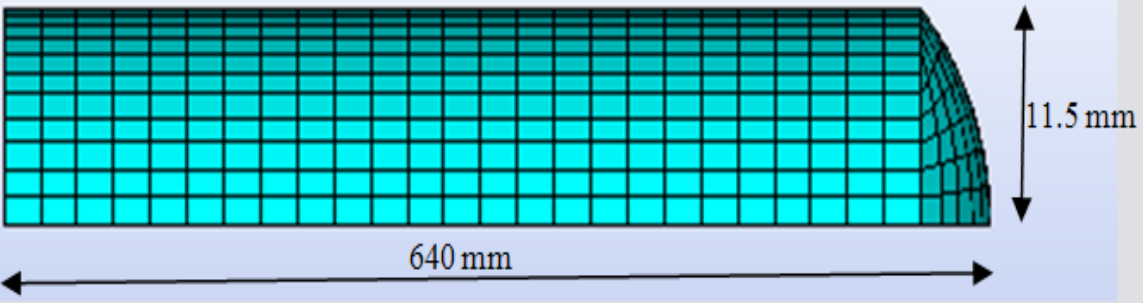

Figure 7: $23 \mathrm{~mm}$ API projectile mesh

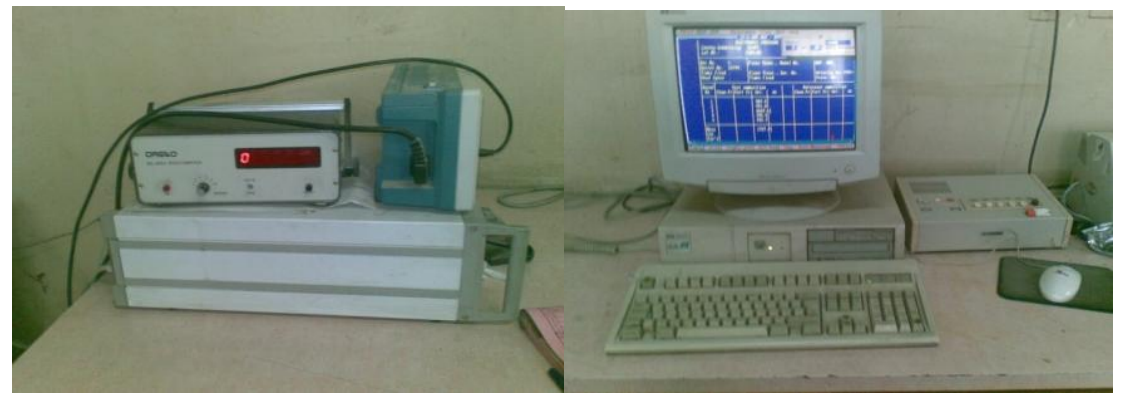




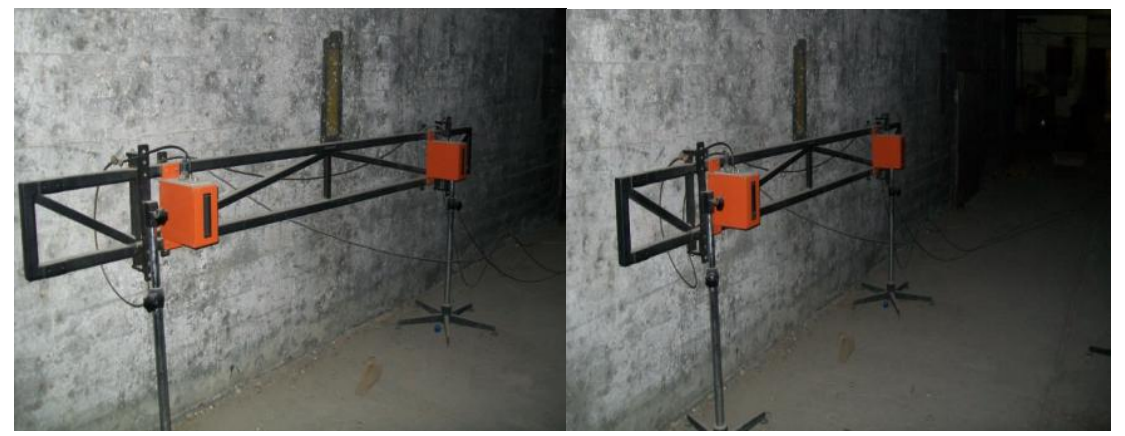

Figure 8: Velocity measurement device.

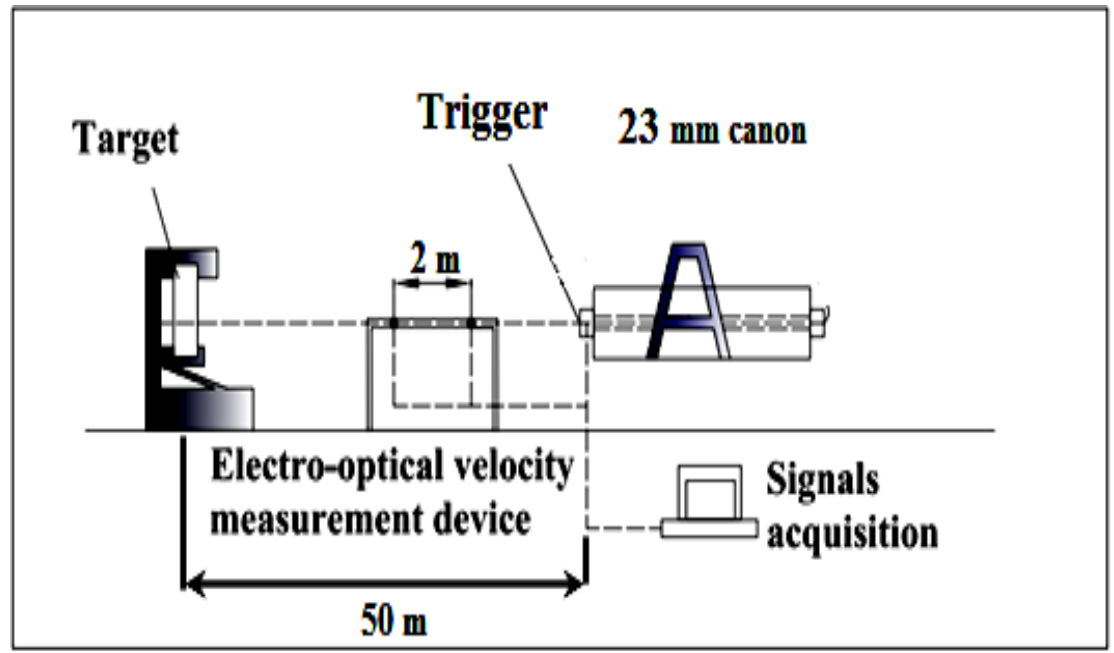

Figure, 9: Penetration depth setup for concrete

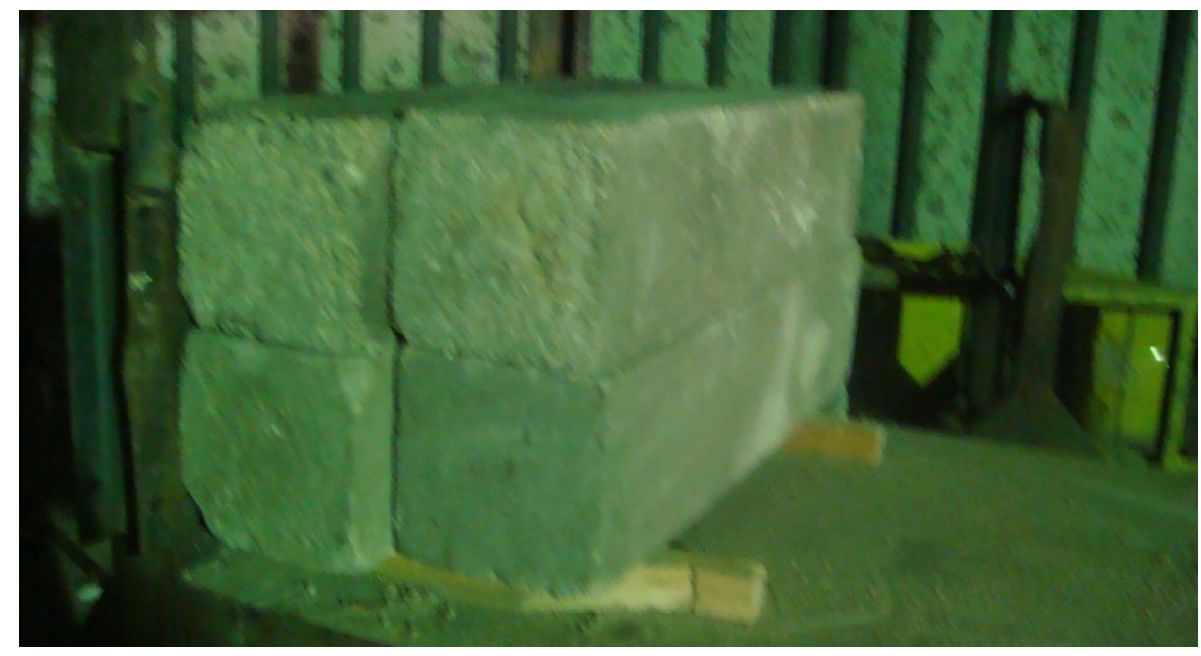

Figure 10: Concrete model. 


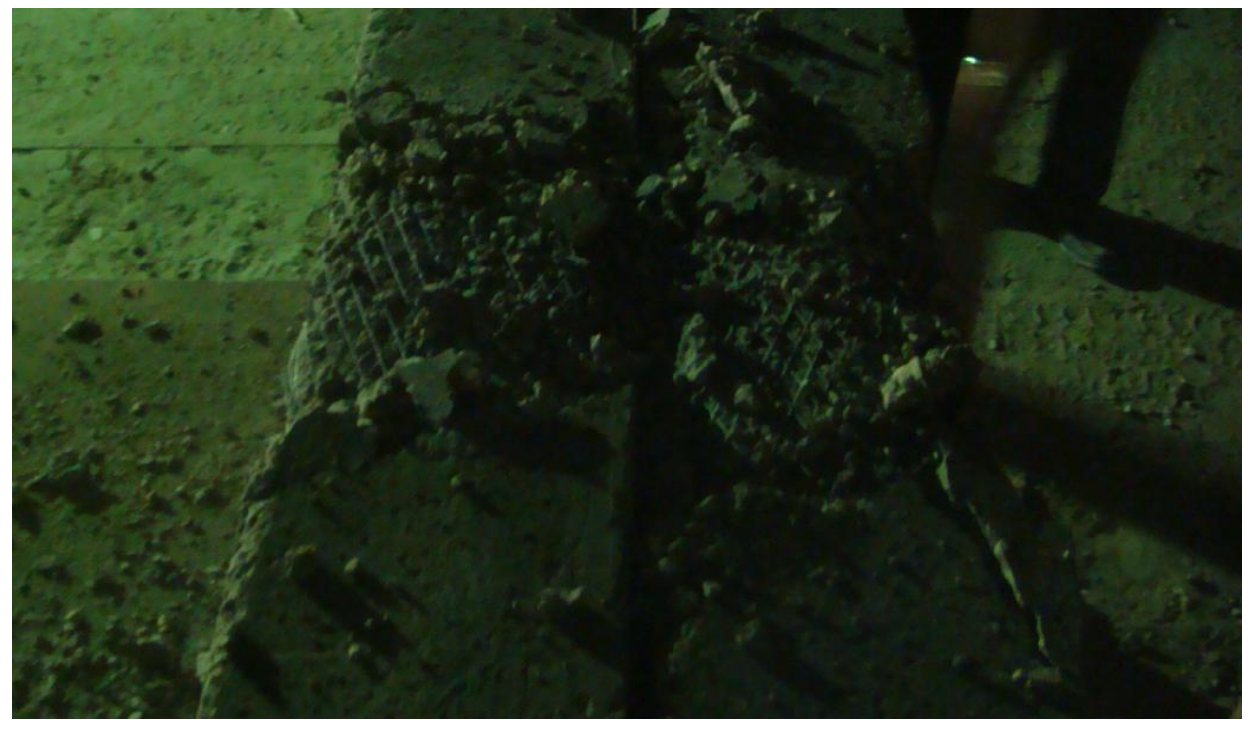

Figure 11-A: Details of Concrete model penetration.

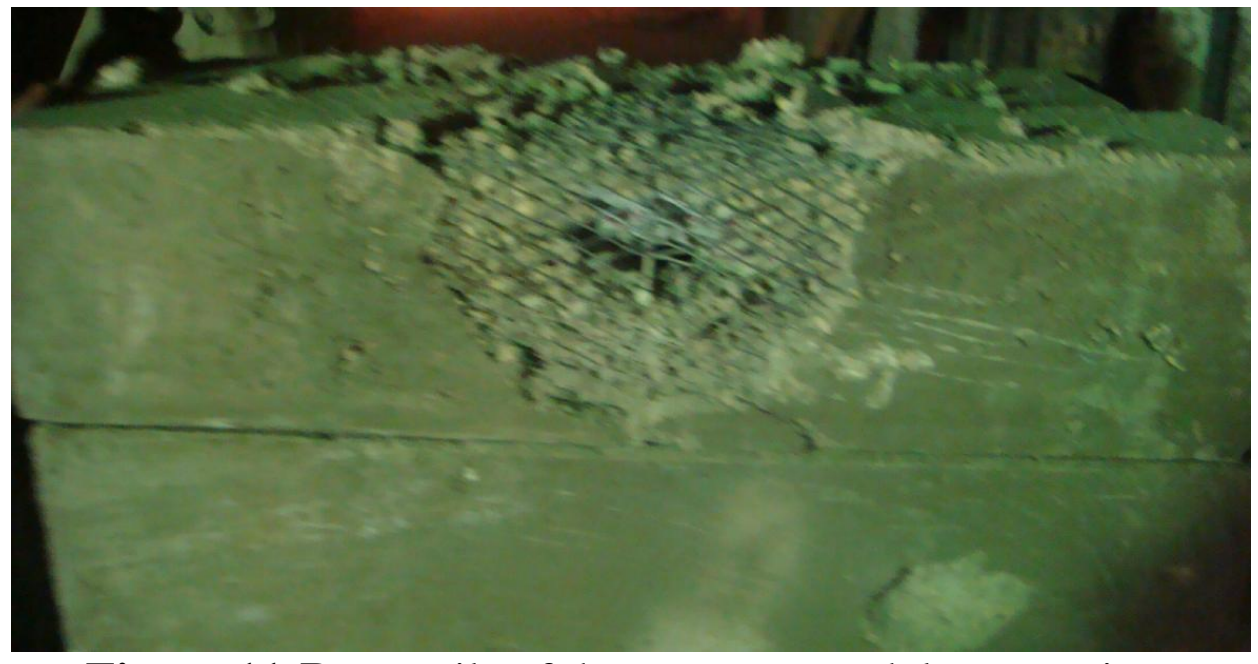

Figure 11-B: Details of the concrete model penetration. 


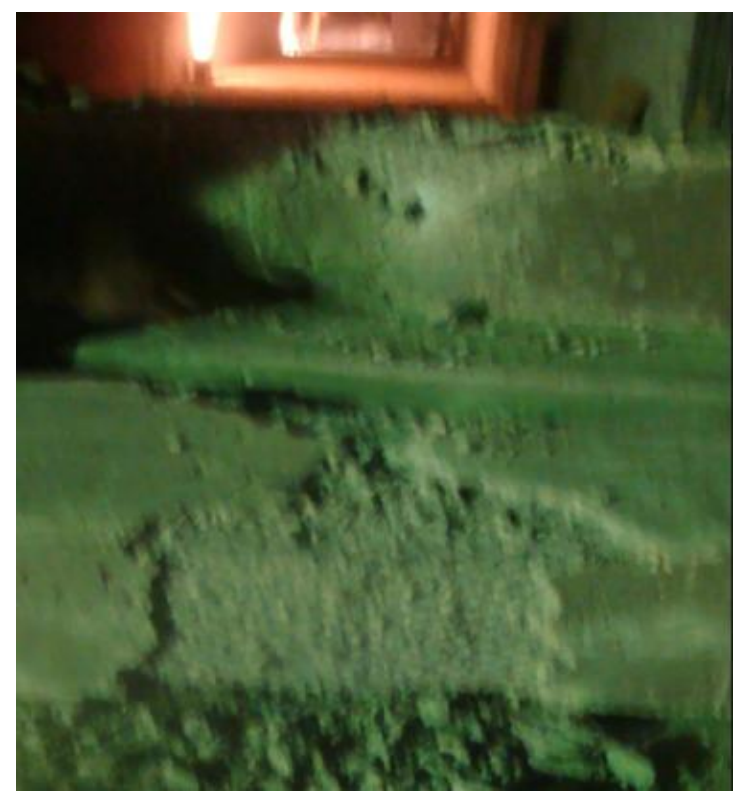

Figure 11-C: Details of the Concrete Model Penetration.

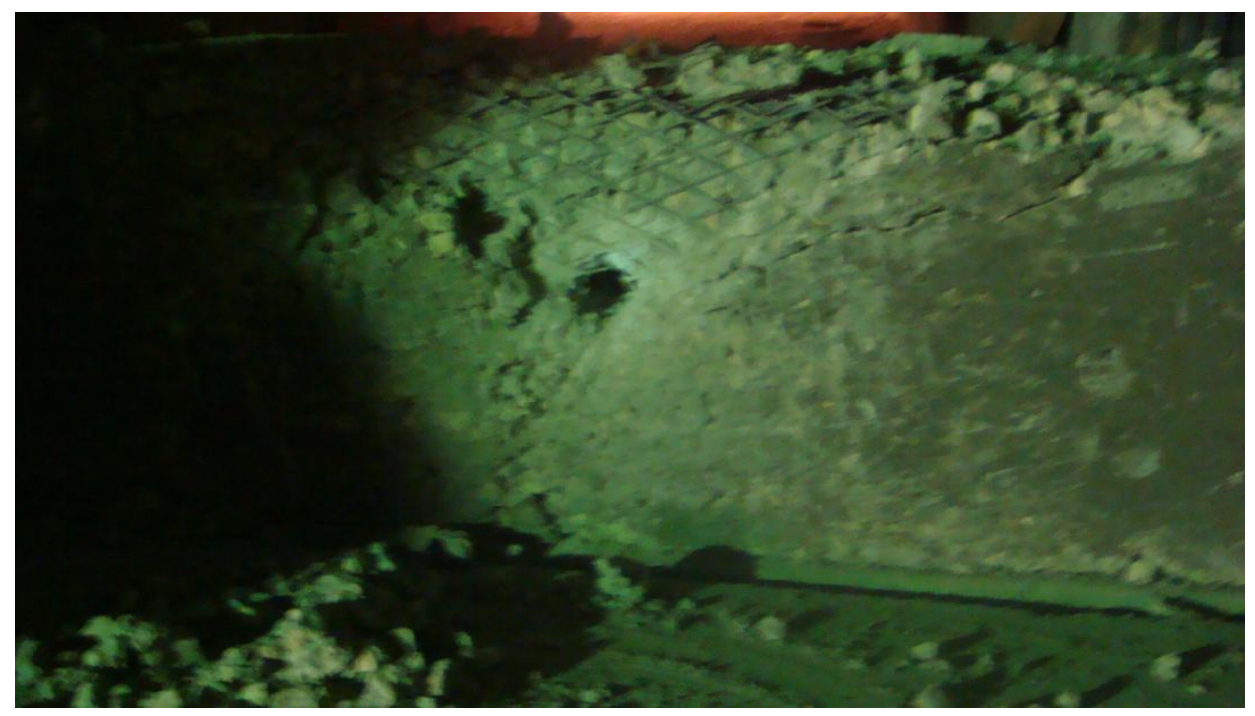

Figure 11-D: Details of the Concrete Model Penetration.

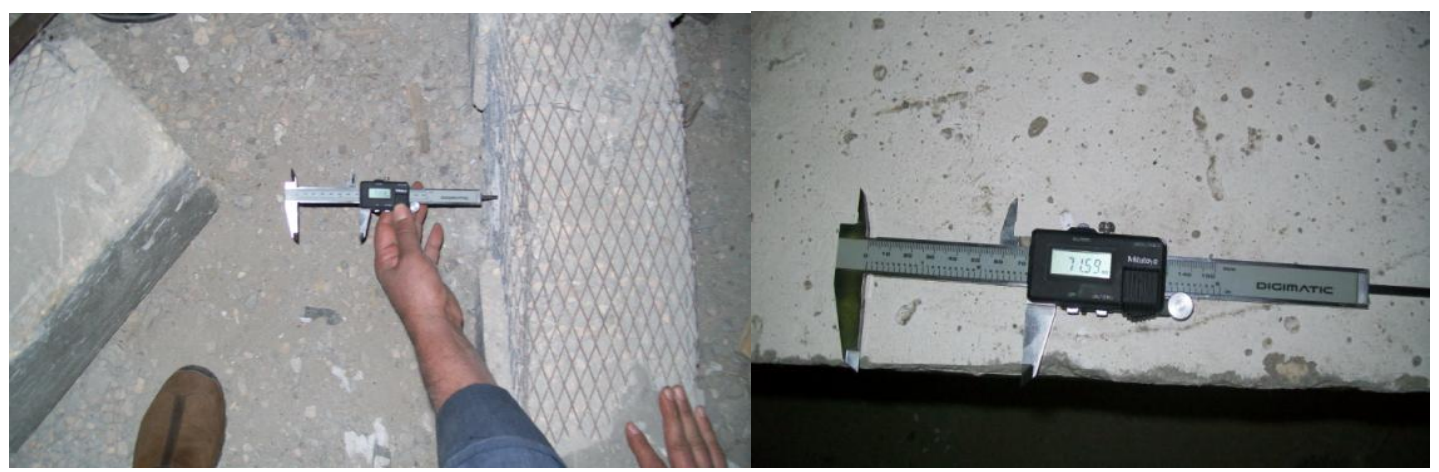

Figure 11-E: Details of the Concrete Model Penetration. 


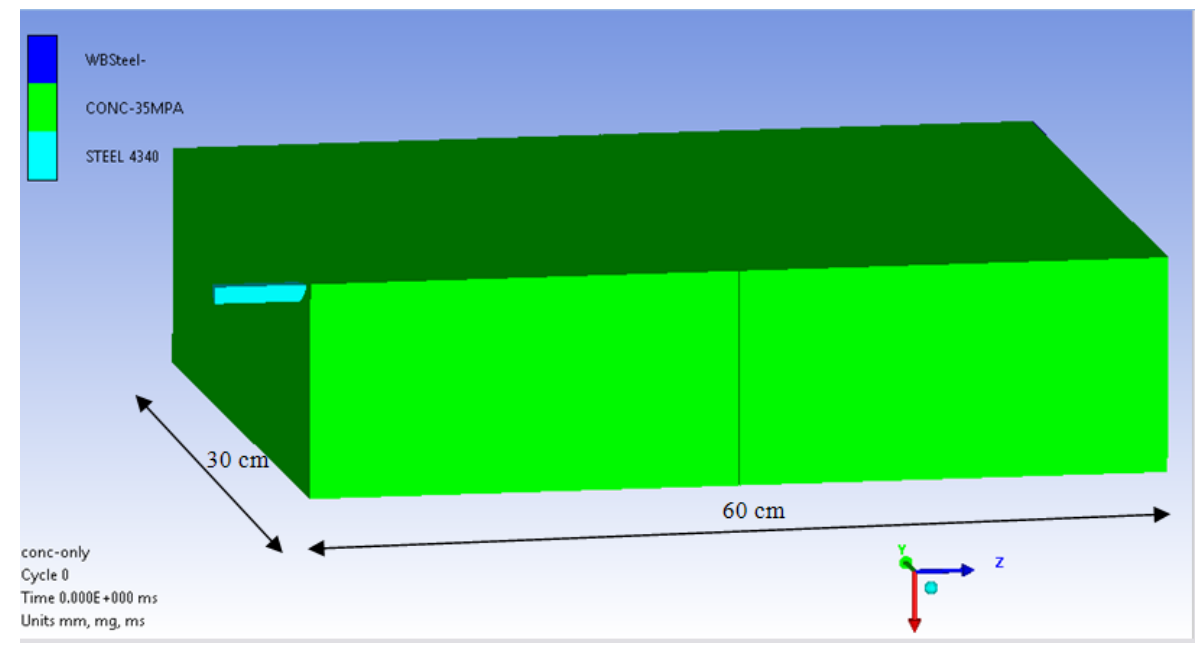

Figure 12: Details of the projectile and Concrete Model.

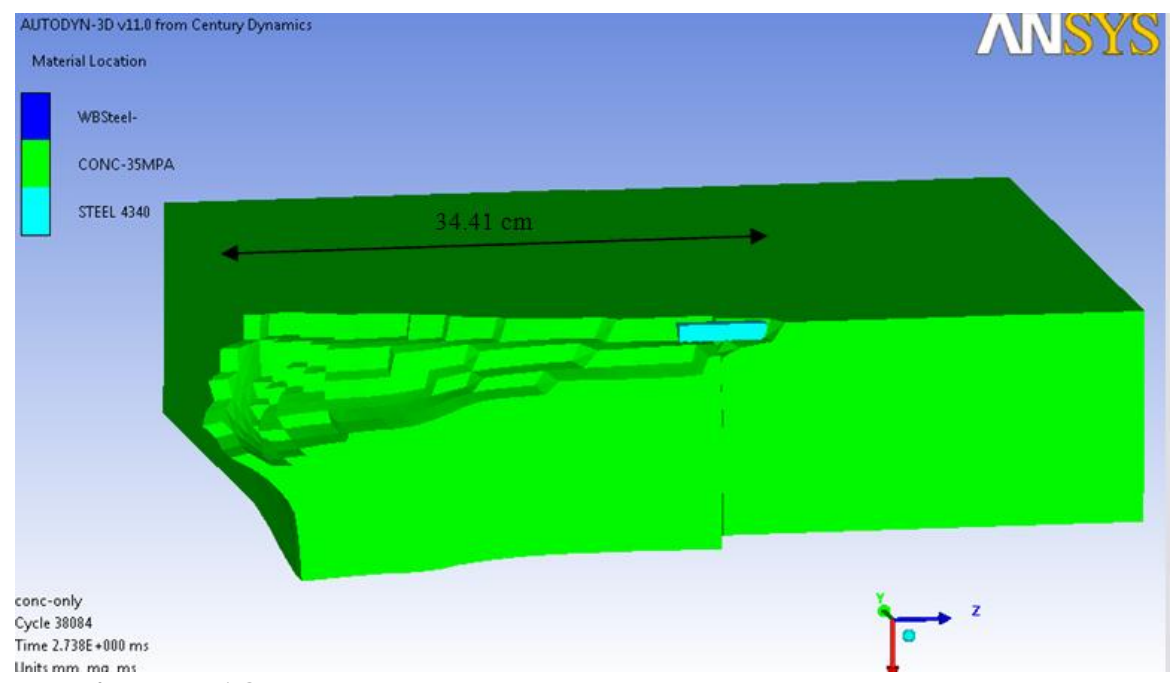

Figure 13: Penetration Depth for the Concrete Model. 


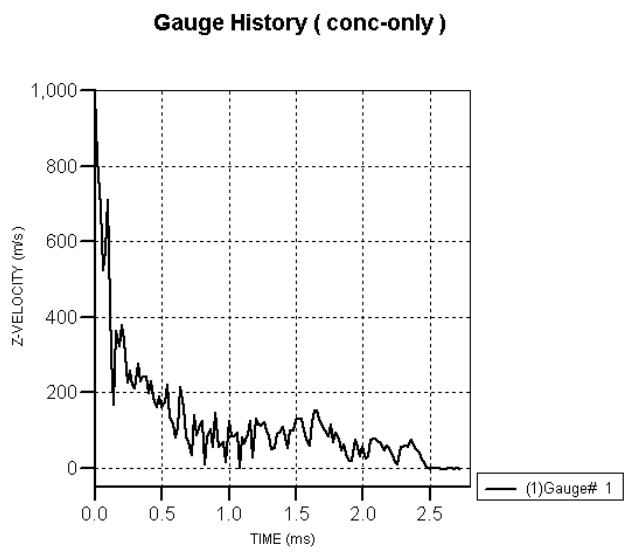

Figure 14: Projectile Velocity Profile.

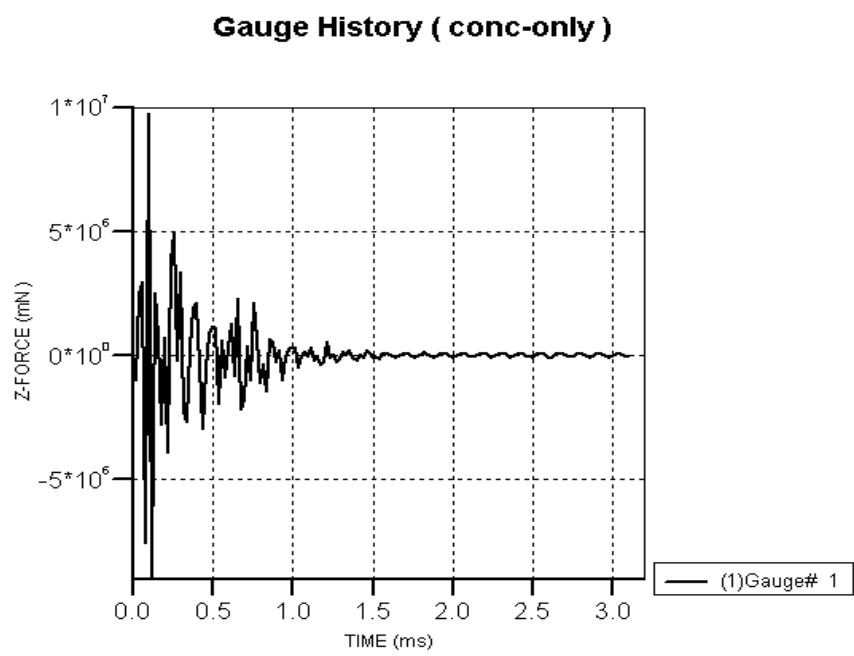

Figure 15: Z-Force Profile. 